\title{
JEJAK ISLAM DI KOTA BINJAI 1887-1956
}

\author{
Yushar $^{1}$, Janita Anggraini Sembiring ${ }^{2}$ \\ Fakultas Ilmu Sosial, Universitas Negeri Medan
}

\begin{abstract}
ABSTRAK
Penelitian ini bertujuan untuk mengetahui proses awal masuknya agama Islam di Kota Binjai, untuk mengetahui perkembangan agama Islam di Kota Binjai, untuk mengetahui tokoh-tokoh yang berpengaruh dalam perkembangan agama Islam di Kota Binjai, untuk mengetahui bangunan-bangunan peninggalan bercorak Islam di Kota Binjai dan untuk mengetahui jejak-jejak Islam yang terdapat di kota Binjai dan masih terdapat peninggalannya hingga sekarang. Penelitian yang dilakukan adalah penelitian dengan menggunakan metode Library Research (metode penelitian kepustakaan) dan Field Research Methode ( metode penelitian lapangan) dengan menggunakan pendekatan deskriptif historis dan teknik yang digunakan studi pustaka dan wawancara. Teknik pengumpulan data yang dilakukan dengan mengumpulkan dokumentasi atau memfoto peninggalan-peninggalan jejak Islam di Kota Binjai. Hasil yang diperoleh dari penelitian penyebaran Islam di Kota Binjai ini tidak terlepas dari peran yang besar dalam penyebaran agama Islam dari Kesultanan Langkat yang berkedudukan di Kota Binjai karena Binjai merupakan bagian dari kesultanan langkat sebelum akhirnya membentuk daerahnya sendiri. Dan juga terdapat peninggalan-peninggalan Islam di Kota Binjai yang berupa masjid, makam, sekolah Islam dan Ulama.
\end{abstract}

Kata Kunci : Islam, Kota Binjai 


\section{PENDAhuluan}

Penyebaran Islam yang terjadi di Asia Tenggara menghasilkan terjadinya akulturasi dan asimilasi budaya lokal sehingga membuahkan budaya baru yang dinamis dan unik. Dan catatan mengenai kerajaan besar islam seperti perlak dimana proses islamisasinya dipengaruhi oleh para pedagang muslim juga menjadikan salah satu bukti penting dalam mengkaji proses masuknya agama islam di Nusantara. Dan proses masuknya agama Islam di Indonesia menjadi kajian yang sangat menarik, karena terkait berbagai aspek yang meliputi perkembangan agama islam di Indonesia itu sendiri. Pada akhir abad ke-13 dan abad ke-14 islam telah membangun komunitaskomunitas niaga yang lebih jelas di kota-kota pelabuhan di Sumatera Utara, Jawa Timur, Campa, dan Pantai Timur Malaya. Penyebaran Islam juga tidak lepas dari orang-orang Asia Tenggara yang pernah ke Mekkah, seperti Sunan Gunung Jati, pendiri Banten-Islam, dan para sufi seperti Hamzah Fansuri, Abdurra'uf as-singkili, dan Syekh Yusuf.

Ketika Islam datang, masyarakat Indonesia telah berada dalam pengaruh Hindu-Buddha yang masing-masing penganutnya hidup berdampingan. Kedatangan kaum muslim yang relatif damai tersebut diterima oleh sebagian masyarakat pribumi Indonesia, terutama kaum bangsawan dan pedagang. Melalui pendekatan budaya, dan melalui para pedagang yang menetap di kota-kota dagang yang kemudian menikah dengan wanita pribumi dan bermukin di suatu wilayah tersebut. Pengenalan Islam sebagai agama pendatang kepada masyarakat Indonesia penganut Hindu-Buddha, berproses cukup damai. Dengan masuknya agama Islam ke Indonesia, otomatis membawa kebudayaan Islam itu sendiri yang berpengaruh pula terhadap kehidupan masyarakat pribumi Indonesia. Islam ikut mewarnai kehidupan tradisi-tradisi yang ada di Indonesia. Segala aktivitas kehidupan masyarakat yang menganut agama Islam, bersumber pada ajaran agama Islam.

Saat Portugis pertama kali muncul di Asia, masyarakat Asia Tenggara masih toleran dan mudah menyerap pengaruh-pengaruh baru, seperti halnya mereka toleran terhadap agama Hindu, agama Buddha dan agama Islam. Tetapi dengan diserangnya 
sistem perdagangan islam oleh portugis secara langsung dan dengan kejam, portugis menimbulkan reaksi yang tajam di sejumlah kota dagang tempat islam sudah kokoh berdiri. Kemakmuran sejumlah kerajaan penting, terutama Aceh dan Banten, sebagian besar bersumber pada pelarian-pelarian dari pusat-pusat yang telah jatuh ke tangan pendatang baru kristen itu, dan pada pengalihan pedagang islam ke pelabuhanpelabuhan mereka yang baru milik orang Islam yang lebih agresif.

Islam masuk ke Sumatera Utara dan menyebar ke daerah-daerah lain melalui Aceh, namun berbeda dengan perkembangan agama Islam di wilayah Sumatera Utara bagian selatan yang dikenal dengan nama Tapanuli, wilayah ini merupakan wilayah yang menerima agama Islam melalui jalur pantai Barat Sumatera seperti dari Barus dan Minangkabau. Kemudian melalui wilayah Tapanuli Selatan banyak terdapat penduduknya yang menjadi pemuka agama dan menyebarkan agama Islam di wilayah Sumatera Timur.

Islam telah mewarnai seluruh aspek kehidupan masyarakat baik secara politik, ekonomi maupun sosial. Pengaruh Islam secara sosial budaya yang begitu kuat membawa perubahan yang sangat signifikan pada kebudayaan dan penghidupan sehingga meninggalkan jejak yang terus-menerus hidup di masyarakat. Jejak Islam sebagai peradaban dapat ditemukan dimanapun Islam itu menapak. Jejak sebagai bukti keberadaan Islam merupakan indikator tentang aktivitas masyarakat muslim. Jadi jejak Islam merupakan suatu hal yang wajar dan layak untuk dikaji. Bukan merupakan suatu yang awam manakala jejak Islam yang bertebaran disetiap daerah yang ada bersentuhan dengan Islam, telah menjadi ladang pengkajian. Di Indonesia saja, jejak Islam sudah ditemukan sejak abad pertama Islam dianut masyarakat. Barus merupakan tempat awal dimana jejak Islam sudah dapat disaksikan. Demikian juga diderah lainnya di Sumatera Utara seperti Perlak, dan Pasai dengan komunitas yang beragam.

Keberadaan Jejak Islam di Kota Binjai merupakan peninggalan budaya, yang menjadi sebuah fenomena menarik untuk di kaji sebagai wujud akulturasi, adaptasi, dan asosiasi yang berlangsung di masyarakat. Perwujudan yang dimaksud diatas masih 
perlu ditelisik secara akademis apalagi masih minimnya penulisan sejarah tentang jejak Islam di Kota Binjai.

Adapun yang menjadi rumusan masalah dalam penelitian ini adalah,bagaimana proses awal masuknya agama Islam di Kota Binjai, bagaimana perkembangan agama Islam di Kota Binjai, mengidentifikasi jejak Islam yang ada di Kota Binjai.

Tujuan dari penelitaian ini adalah untuk mengetahui bagaimana proses awal masuknya agama Islam Di Kota Binjai. Siapa orang-orang yang berperan penting dalam penyebaran agama Islam di Kota Binjai. Dan untuk mengetahui bagaimana perkembangan agama Islam di Kota Binjai sejak awal masuknya Islam dari Kesultanan Langkat hingga saat Binjai mulai memerintah daerahnya sendiri sebagai daerah otonom. Serta untuk mengetahui apa saja bangunan serta peninggalan Islam dalam sejarahnya di Kota Binjai. Peninggalan-peninggalan yang berupa kisah tokoh, makam, masjid dan lainnya. Dalam suatu penelitian ilmiah perlu didukung oleh suatu metode penelitian. Metode kualitatif yang menggunakan hermenitika berupa interpretasi terhadap pikiran, perkataan dan perbuatan. Fungsi dari pada metode penelitian tersebut sangatlah penting karena merupakan faktor penentu dari proses pengumpulan proses informasi dan berperan penting terhadap berhasil tidaknya suatu penelitian.

Dalam penelitian ini, penulis menggunakan metode penelitian lapangan (field research) dikombinasikan dengan penelitian kepustakaan (library research). Yaitu dengan mengumpulkan data - data secara objektif berdasarkan hasil wawancara warga Kota Madya Binjai.

\section{PEMBAHASAN}

Awal sejarah Kota Binjai dahulunya merupakan kampung kecil yang terletak di tepi Sungai Bingai. Binjai sebenarnya adalah nama suatu pohon besar, rindang, tumbuh dengan kokoh di tepi Sungai Bingai yang bermuara di Sungai Wampu. Pada

Tahun1822, Binjai telah dijadikan bandar/pelabuhan dengan mengekspor hasil pertanian lada yang berasal dari perkebunan lada di sekitar Ketapangai (Pungai) atau Kelurahan Kebun Lada/Damai. 
Perkembangan zaman terus berjalan, pada tahun 1864 Daerah Deli telah dicoba ditanami tembakau oleh pioner Belanda bernama J.Nienkyis dan 1866 didirikan Deli Maatschappiy. Usaha untuk menguasai Tanah Deli oleh orang Belanda tidak terkecuali dengan menggunakan politik pecah belah melalui pengangkatan datuk-datuk. Usaha ini diketahui oleh Datuk Kocik, Datuk Jalil dan Suling Barat yang tidak mau bekerja sama dengan Belanda bahkan melakukan perlawanan.

Bersamaan dengan itu Datuk Sunggal tidak menyetujui pemberian konsensi tanah kepada perusahaan Rotterdanmy oleh Sultan Deli karena tanpa persetujuan. Dibawah kepemimpinan Datuk Sunggal bersama rakyatnya di Timbang Langkat (Binjai) dibuat Benteng pertahanan untuk menghadapi Belanda. Dengan tindakan datuk Sunggal ini Belanda merasa terhina dan memerintahkan Kapten Koops untuk menumpas para Datuk yang menentang Belanda. Dan pada 17 Mei 1872 terjadilah pertempuran yang sengit antara Datuk dan masyarakat dengan Belanda. Peristiwa perlawanan inilah yang menjadi tonggak sejarah perjuangan Binjai. Perjuangan para datuk/rakyat terus berkobar dan pada akhirnya pada 24 Oktober 1872 Datuk Kocik, Datuk Jalil dan Suling Barat dapat ditangkap Belanda dan kemudian pada tahun 1873 dibuang ke Cilacap. Pada tahun 1917 oleh Pemerintah Belanda dikeluarkan Instelling Ordonantie No.12 dimana Binjai dijadikan Gemente dengan luas 267 Ha. Pada tahun 1942 - 1945 Binjai di bawah pemerintahan Jepang dengan kepala pemerintahannya adalah Kagujawa dengan sebutan Guserbu dan tahun 1944/1945.

Proses awal dan berkembangnya agama Islam di Kota Binjai. Sejak awal Kota Binjai merupakan salah satu bagian dari wilayah Kesultanan Langkat. Kesultanan Langkat merupakan wilayah yang telah mengenal agama Islam melalui penyebaran Islam oleh pemuka agama yang berasal dari Aceh dan Minangkabau yang masuk ke Sumatera Timur pada waktu itu. Sehingga pada saat Binjai mulai membentuk dan mengatur wilayahnya sendiri yang tertulis dalam undang-undang No.9 tahun 1956tentang pembentukan daerah-daerah otonom, masyarakat Binjai telah mengenal agama Islam. 
Islam masuk ke wilayah Kesultanan Langkat tidak terlepas dari kerajaan Aru yang telah mengenal Islam sejak pertengahan abad ke-13. Akibat kekalahan Kerajaan Aru yang berperang dengan Kerajaan Aceh dibawah pimpinan Sultan Iskandar Muda sekitar abad ke-16 yang sedang melakukan perluasan hingga ke wilayah Sumatera Timur menyebabkan hancurnya kerajaan Aru, yang kemudian didirikanlah Kerajaan baru di derah Hamparan Perak, yang merupakan awal mula didirikannya Kerajaan Langkat.

Sehingga agama Islam telah ada di Sumatera Timur sejak akhir abad ke-13 dan menyebabkan banyak daerah di Sumatera Timur yang mulai menganut agama Islam di bawah kerajaan Aru pada waktu itu termasuk Kesultanan langkat yang juga merupakan wilayah Kerajaan Aru. Sehingga Binjai telah mengenal agama Islam sejak masih dibawah kekuasaan Kesultanan Langkat.

Proses awal masuknya Islam di Kota binjai berawal dari Islam masuk ke Sumatera Utara dan menyebar ke daerah-daerah lain melalui Aceh, namun berbeda dengan perkembangan agama Islam di wilayah Sumatera Utara bagian selatan yang dikenal dengan nama Tapanuli, wilayah ini merupakan wilayah yang menerima agama Islam melalui jalur pantai Barat Sumatera seperti dari Barus dan Minangkabau. Kemudian melalui wilayah Tapanuli Selatan banyak terdapat penduduknya yang menjadi pemuka agama dan menyebarkan agama Islam di wilayah Sumatera Timur.

Diawal berdirinya masyarakat Kota Binjai sudah menganut Islam. Karena pertama sekali Kota Binjai dihuni melalui perluasan wilayah yang dilakukan oleh kerajaan Aceh ke wilayah Sumatera Timutr yang menganut agama Islam.

Kota Binjai juga berkembang dengan pesat karena keberhasilan Kesultanan Langkat. Geografis kota Binjai yang starategis terletak diantara muara Bingai dan aliran Sungai Wampu menjadikan kota ini ramai di datangi pedagang. Hal ini menjadi daya tarik bagi para pedagang untuk melakukan transaksi dagang di Kota Binjai. Para pedagang yang datang kebanyakan dari negara tetangga dan sudah memeluk agama Islam. Sehingga secara tidak langsung, agama Islam juga diperkenalkan oleh para pedagang muslim di Kota Binjai. 
Dalam proses dan masuknya Islam di Kota Binjai tidak pernah tersentuh oleh pengaruh agama Hindu-Buddha sebelum agama Islam masuk. Agama Hindu-Budha masuk setelah agama Islam menjadi agama mayoritas masyarakat di Kota Binjai. Namun ada pula kepercayaan masyarakat Kota Binjai yang bersifat kepada animisme dan dinamisme. Agama Islam berkembang pesat di Kota Binjai karena tokoh ulama setempat giat melakukan dakwah dan didukung oleh Kesultanan Langkat yang memerintah Kota Binjai. Pada awalnya agama Islam berkembang pesat di Kota Binjai karena Kesultanan Langkat mendukung penuh misi penyebaran agama Islam. Didalam melaksanakan pemerintahannya Sultan Langkat berpegang teguh kepada ajaran Islam. Karena ajaran Islam tidak bertentangan dengan hakekat manusia.

Kesultanan Langkat juga menetapkan syarat juga menetapkan syarat bagi siapa yang menetap dan menjadi masyarakat Kota Binjai terlebih dahulu harus memeluk agama Islam. Kesultanan Langkat juga membuka luas lapangan pekerjaan baik di bidang pertanian yang mencapai swasembada pangan maupun bidang perdagangan. Kota Binjai terkenal sebagai kota yang aman dan strategis untuk bidang perdagangan. Karena itulah banyak masyarakat luas yang menetap di Kota Binjai.

\section{A. Mengidentifikasi Jejak Islam Di Kota Binjai}

\section{Masjid Raya Kota Binjai}

Jejak Islam merupakan rangkaian peristiwa-peristiwa yang terjadi dalam perkembangan agama Islam. Jejak Islam sudah ditemukan sejak abad pertama Islam dianut masyarakat. Jejak islam atau peradaban islam dimulai sejak abad ke-7 M dimana para pedagang-pedagang Muslim Arab, Persia, sampai ke kepulauan Indonesia. Barus merupakan tempat awal dimana jejak Islam sudah dapat disaksikan. Demikian juga diderah lainnya di Sumatera Utara. Keberadaan Jejak Islam di Kota Binjai merupakan peninggalan budaya, yang menjadi sebuah fenomena menarik untuk di kaji sebagai wujud akulturasi, adaptasi, dan asosiasi yang berlangsung di masyarakat.Masjid Raya Binjai ini yang didirikan pada tahun 1887 dan peletakkan batu pertamanya oleh $\mathrm{H}$. Musa Sultan Langkat namun Masjid resmi dibuka (diresmikan) oleh T Sultan Abdul 
Aziz Langkat II pada tahun 1890. Sejak diresmikan, masjid ini digunakan penduduk muslim di kota Binjai untuk shalat wajib dan sukarela dalam kegiatan keagamaan lainnya sampai sekarang.

Masjid Raya Binjai didirikan pada tahun 1887 oleh Tengku Haji Musa alKhalid al-Mahadiah Muazzam Shah (Tengku Ngah) bin Raja Ahmad, yang menjabat 1840-1893 periode (Sultan Langkat I). Masjid Raya Binjai merupakan kebanggaan masyarakat lokal Kota Binjai yang jelas tidak bisa lepas dari pengaruh Kesultanan Langkat pada waktu itu. Sebelum status kotamadya, Binjai adalah ibukota Langkat yang kemudian dipindahkan ke Stabat. Bukti yang menunjukkan bahwa masjid ini secara langsung berkaitan dengan Kesultanan Langkat adalah bahwa terobosan masjid ini pada tahun 1887 oleh Sultan Langkat Musa HI Namun Masjid resmi dibuka (diresmikan) oleh T Sultan Abdul Aziz Langkat II pada tahun 1890 Sejak diresmikan, masjid ini digunakan Muslim di kota Binjai untuk shalat wajib dan sukarela dan kegiatan keagamaan lainnya sampai sekarang.

Masjid itu kemudian direnovasi pada tahun 1924 sehingga terlihat seperti sekarang ini. Dalam perkembangan selanjutnya, baik selama atau setelah Kesultanan Langkat II, masjid ini menjadi pusat berbagai kegiatan, apakah itu terkait dengan komunitas agama Islam, sosial dan budaya di kota Binjai. Hal ini dibuktikan dengan digelarnya MTQ tingkat pertama (Musabaqah Tilawatil Qur'an) Sumatera Timur yang diprakarsai oleh Syaikh H. Abdul Halim Hasan di Binjai pada tahun 1951 di halaman Masjid Raya Binjai.

Masjid ini memiliki nilai-nilai dan sejarah perjuangan bangsa Indonesia, termasuk masjid tertua di Sumatera Utara (sekarang berusia 124 tahun), yang sebelumnya bernama Masjid Jami' (kemudian berubah namanya menjadi Masjid Binjai). Pembangunan masjid itu sendiri bukan tanpa hambatan. Pada masa Tuanku Haji Musa, pembangunan masjid belum selesai dan belum digunakan sebagai tempat ibadah. Kemudian setelah Tuanku Haji Musa meninggal, posisinya digantikan oleh putranya Sultan Tuanku Abdul Aziz bin Abdul Jalil Rahmat Shah Sultan Haji Musa (1893-1927). Masa Depan Masjid Raya Binjai di konstruksi hingga selesai dan 
kemudian diresmikan penggunaannya sebagai tempat beribadah dan dakwah.

Masjid ini digunakan untuk pertama kalinya shalat Jumat pada tahun 1890 oleh Tengku Abd. Aziz (Sultan Langkat II). Ia juga berperan dalam pembangunan berkelanjutan sejumlah masjid yang telah dirintis oleh Sultan Langkat I, dengan mengumpulkan hasil gaji raja-raja dan Datok-Datok masing-masing daerah di Langkat. Sejak diresmikan, masjid ini mulai digunakan sebagai tempat ibadah dan masih menjadi salah satu yang terbesar dan Masjid tertua di kota Binjai.

Awal berdirinya, peran Masjid Binjai ini dalam Islam mengalami perkembangan yang sangat signifikan. Namun, sebagai masjid Kesultanan selalu diisi dengan kegiatan lain yang melibatkan pengajian dari bapak-bapak atau ibu-ibu dan remaja, masjid ini tidak memiliki kegiatan rutin seperti pengajian masjid lainnya. Hal ini karena Masjid Binjai terletak di pusat kota di Jalan Binjai yaitu KH Wahid Hasyim, Kecamatan Binjai Kota, dimana masyarakat sekitar masjid yang mayoritas etnis Tionghoa / Cina. Sementara masyarakat Muslim yang melakukan kegiatan berdoa di dimasjid ini adalah mayoritas pendatang dan pedagang yang melakukan aktifitas dagang di halaman-halaman masjid Raya Binjai ini setiap hari.

Pada tahun 1922, didirikan Yayasan pendidikan Islam Al-Ishlahiyah di samping masjid Raya Binjai ini sebagai hadiah keluarga Sultan Langkat, yang sampai sekarang masih eksis sebagai proses pembelajaran di Langkat dan di kota Binjai, bahkan sekarang berkembang pesat, terbukti dengan pembukaan Sekolah Tinggi Agama Al-Islahiyah (stais).

\section{Masjid Jami’ Limau Sunde}

Masjid Jami' dibangun pada tahun 1889 yang sekarang terletak di kelurahan Limau sunde Kecamatan Binjai Barat. Masjid ini dahulunya dibangun oleh masyarakat Limau sunde dengan sukarela dan dana sedanya. Luasnya sekitar 17x12 m. yang dimana bentuknya seperti masjid joglo. Pada awal mula perencanaan pembangunan masjid tersebut terdapat suatu masalah yang bermula dari seorang pemilik tanah yang ingin mewaqafkan tanahnya untuk pembangunan masjid, namun ada satu orang warga 
lain yang ingin jika masjid tersebut dibangun di atas tanahnya pula. Sehingga akhirnya diputuskan bahwa masjid akan dibangun diatas kedua tanah mereka yang memang letaknya bersebelahan.

Masjid ini awalnya di bangun dengan dana sukarela dari masyarakat kampung dan hanya di bangun sederhana dengan material kayu. Karena struktur bangunannya yang terbuat dari kayu, lama kelamaan bangunan masjid mulai rusak karena terkena air dari banjir. Renovasi pertama dilakukan pada tahun 1972 dan tidak banyak perombakan yang dilakukan pada masjid tersebut. Pada tahun 1987 masjid Jami' di bongkar habis dan dilakukan pembangunan ulang yang dimana Gubernur Sumatera Utara pada saat itu memberikan bantuan dana sekitar 5 juta rupiah dan terdapat sumbangan pula dari Bambang Triatmodjo dan istrinya Halimah serta ayahnya yaitu Abdula Kamil. Renovasi ini dilakukan sekitar 3 minggu lamanya. Dan pada minggu keempat tepatnya sebelum hari raya idul fitri Masjid Jami' sudah selesai di renovasi. Kemudian pada tahun 1991 barulah dibangun menara dari masjid Jami tersebut. Salah satu yang menjadi ciri khas dari Masjid Jami' ini ialah bentuk mimbarnya yang berada di tengah lantai Masjid dan menyatu dengan tanah atau lantai. Dan sejak awal hingga renivasi yang terakhir, mimbar ini tidak pernah dirubah bentuknya atau posisinya, hanya saja di perbaiki materialnya agar lebih kokoh.

Kepala desa pertama yang menjabat di desa Limau Sunde ini bernama Tengku Kolok yang kemudian digantikan oleh anaknya yang bernama Tengku Tehat yang juga memberikan kontribusi yang baik dalam perkembangan agama Islam di Desa Limau Sunde. Cerita ini disampaikan oleh bapak Darma Sapta Lubis yang sekarang menjabat sebagai seksi pembangunan di Badan Kepengurusan Masjid Jami' di Kelurahan Limau Sunde.

\section{Makam}

Komplek makam tua terdapat di beberapa tempat di kota Binjai. Keberadaan makam tua ini semakin memperkuat keberadaan Islam di kota Binjai sudah ada sejak abad ke 18. Kebanyakan makam tua yaang ditemukan dan masih ada hingga sekarang 
merupakan makam-makam orang besar, seperti makam Sultan, Syekh, Datuk Muda, Ok (Orang Kaya), yang dahulu pernah berperan dalam perkembangan agama Islam di Kota Binjai.

Terdapat makam tua di Kota Binjai yang merupakan makam dari Syeikh Muhammad Isa yaitu tahun 1870. Namun berbeda dari kebanyakan wilayah lain yang merupakan hasil pemecahan dari suatu kesultanan, di Kota Binjai sangat sedikit terdapat makam para bangsawan melayu yang dulunya pernah berkuasa di Binjai yang saat itu dibawah Kesultanan Langkat. Hampir semuanya di makamkan di daerah Langkat. Dan terdapat beberapa makam tua lain di pemakaman Limau Sunde namun kebanyakan rusak dan tidak diperbaiki lagi.

Ada beberapa makam tua yang ditemukan di wilayah Kota Binjai antara lain : Makam KH.Abdul Qarim merupakan salah satu ulama terkemuka di Kota Binjai, beliau sempat menjabat sebagai kepala madrasah Jamiyatul Khairiyah dulunya madrasah ini di pimpin al ustad H.Muhammad Nur Al-Faqih namun setelah pembangunan madrasah yang baru disebelah mesjid raya Bijai saat ini Madrasah Jamiyatul Khairiyah di pimpin oleh Kh.Abdul Qarim . Dalam membina dan mengasuh madrasah ini beliau dibantu oleh Almarhum KH.Abdul Halim Hasan. KH.Abdul Qarim memimpin dan mengasuh madrasah hanya sampai tahun 1927. Hal ini disebabkan karena beliau diangkat dan ditugaskan sebagai mufti menggantikan al ustad Muhammad Nur Al Faqih.

Salah satu bukti sejarah yang di tinggalkan oleh Almarhum K.H.Abdul Qarim ialah mesjid KH.Qarim yang berada di Jalan KH.Abdul Qarim dikeluruhan Rambung Dalam Kecamatan Binjai Selatan. Pengaruh yang diberikan Almarhum KH.Abdul Qarim terhadap masyarakat di kota Binjai sangat besar, sehingga nama beliau di abadikan menjadi salah satu nama di Kota Binjai. Beliau di makamkan pada tahun 1870 di kecamatan Rambung Barat Binjai Selatan dan letaknya di pekarangan Masjid Kyai Karim. Abdul Halim Hasan lahir di Binjai pada tanggal 15 mei 1901. Abdul Halim Hasan beraktifitas dalam dunia kelimuan Islam. Beliau mengajar di Universitas Islam Sumatera Utara. Pribadi seorang guru yang dimiliki oleh Abdul Halim Hasan 
mencerminkan seorang guru yang ideal yang sederhana. Kesederhanaan beliau dapat dirasakan oleh orang-orang yang bergaul dengan beliau, baik dari kalangan mahasiswa, tokoh akademis maupun masyarakat pada umumnya. Kesederhaan itu tidak hanya terlihat dalam penampilan beliau tapi juga dalam bertutur dan mengekspresikan ideide beliau baik dalam tulisan, perkuliahan ataupun dalam aktifitas lainnya. . KH.Abdul Qarim memimpin dan mengasuh madrasah hanya sampai tahun 1927. Hal ini disebabkan karena beliau diangkat dan ditugaskan sebagai mufti menggantikan al ustad Muhammad Nur Al Faqih.

\section{Yayasan-Yayasan Pendidikan Islam Di Kota Binjai}

\section{a. Yayasan Al-Ishlahiyah Binjai}

Yayasan Al-Ishlahiyah Binjai merupakan salah satu Yayasan pendidikan islam yang tertua di Kota Binjai. Yayasan Al-Ishlahiyah adalah salah satu perguruan swasta di kota Madya Binjai yang bergerak di bidang pendidikan agama Islam. Madrasah ini mengelola pendidikan mulai tingkat Ibtidaiyah, Tsanawiyah, Aliyah sampai tingkat Perguruan Tinggi. Jumlah lulusan pada setiap tingkat tersebut sangat banyak.

Melihat kiprah dan peran madrasah ini sejak berdiri pada tahun 1922 hingga sekarang dalam upaya turut mencerdaskan kehidupan bangsa yang berakhlak , bermoral, dan bertakwa kepada Allah Yang Maha Kuasa,bahkan lebih dari itu telah berhasil melahirkan ulama - ulama berkaliber nasional dan pejuang-pejuang kemerdekaan pada masa dahulu.

Madrasah ini telah banyak berjasa bukan saja dalam menghasilkan ulamaulama yang terkemuka tapi juga menjadi sarana pengkaderan pejuang-pejuang tangguh dalam merebut dan mempertahankan kemerdekaan Republik Indonesia.Tercatat sejumlah nama pejuang yang telkah diabadikan pada "batu bertengger" yang terletak di depan Madrasah yang di resmikan oleh Walikota Binjai Bapak Alm.H.Abadi Barus pada tanggal 10 November 1996 yang lalu .

Salah satu ulama terkemuka yang telah banyak menyisihkan waktunya untuk mengasuh Madrasah ini dan sekaligus menjadi Mudir (Kepala Sekolah) sejak tahun 
1927 sampai masa penyerahan kedaulatan adalah Alm.KH.Abdul Halim Hasan.Dan ulama-ulama besar lainya yang telah menghidupkan Madrasah ini seperti Alm.KH.A Karim ,Alm.Ustadz H.Zainal Ariffin Abbas,Alm Al ustadz Abdul Rahim Haitami,Alm.Al ustadz Bustami Ibrahim. A.Periode Pertama

Jamiyatul Khairiyah (22 November 1922) Madrasah Al-Ishlahiyah berdiri sejak tahun 1922 tepatnya 22 November 1922.Pada awal berdirinya madrasah ini bernama Madrasah "Jammiyatul Khairiyah" sesuaikan dengan nama perkumpulan yang mendirikanya yaitu Jamiyyatul Khairiyah perkumpulan ini terdiri saudagar saudagar islam yang ada di Binjai terutam mereka yang bertoko di kedai panjang (sebutan rumah toko di kota Binjai sekarang ). B. Periode Kedua Arabiyah School (Tahun 1930) Pada pertumbuhan selanjutnya, seiring dengan tuntutan dari perjuangan, dan untuk menyesuaikan diri dengan situasi perkembangan zaman pada masa itu, alm. K.H. Abd. Halim Hasan mengganti nama Madrasah Jami’yatul Khairiyah menjadi “Arabiyah School". Hal ini dimaksudkan agar madrasah ini tidak hanya sekedar lembaga pendidikan agama yang kaku tetapi mampu mengikuti perkembangan zaman. C. Periode Ketiga Al-Ishlahiyah (1950) Perguruan Al-Ishlahiyah mengembangkan perguruan nya mulai dari taman kanak-kanak hingga perguruan tinggi. Pada tahun 1989 oleh pengurus yayasan Al-Ishlahiyah telah membuka secara resmi Institut Agama Islam Al-Ishlahiya (IAIA) yang terdiridari dua fakultas yaitu: Fakultas Tarbiyah dan Fakultas Dakwah.

\section{b. Yayasan Pendidikan Al Jam'iyatul Washliyah Kota Binjai}

Al jam'iyatul washliyah berdiri di Binjai tahun 1938 ,organisasi ini mulai menunjukan perkembangannya di berbagai bidang. Perkembangan tersebut di tuju untuk mewujudkan Al Jam'iyatul washliyah sebagai suatu organisasi yang eksis dalam kehidupan masyarakat dan bernegarayang memiliki peranbesar pada waktu itu. Hal tersebut juga di laksanakan untuk mencapai tujuan tujuan Al jam'iyatul washliyah sebagai suatu organisasi kemasyarakatan yang berhaluan Islam. Al jam'iyatul washliyah bertujuan menegakkan ajaran Islam untuk terciptanya masyarakat yang 
beriman, bertaqwa, cerdas, amanah, adil, makmur, dan diridhai Allah SWT. Sejak tahun 1940 di Binjai, mulai dibangun lembaga pendidikan atau perguruan. Di kota Binjai Al jam'iyatul washliyah telah mempunyai perguruan mulai dari Tadjhizi, Ibtida'i,danTsanawiyah.

pada sejarahnya Al-Jam'iyatul Washliyah di Binjai ini dibawa oleh orang-orang mandailing. Awalnya mereka itu bertujuan untuk membentuk suatu pengajian untuk belajar agama Islam. Gedung awal yang digunakan untuk pengajian ini berbentuk seperti rumah panggung, dahulunya terletak tepat berada didepan madrasah AlJam'iyatul Washliyah yang berada di Binjai Kota. Dan mereka juga membuat perkumpulan-perkumpulan untuk belajar mengaji di musholla-musholla sekitarnya. Dan kemudian mereka jugalah yang merupakan pengurus Al-Jam'iyatul Washliyah dengan mendirikan madrasah dan lembaga formal untuk anak-anak usia belajar di Binjai pada tahun 1940.

Awalnya sistem pendidikan Al-Jam'iyatul Washliyah di Binjai bersifat non formal, karena hanya di lakukan secara berkelompok-kelompok di rumah ataupun di musholla. Baru kemudian atas kesadaran para pengurus Al-Jam'iyatul Washliyah mereka pun membangun sebuah lembaga pendidikan dengan tingkat Tadjhizi, Ibtida'i, dan kemudian Tsanawiyah pada tahun 1940. Adapun jenjang sekolah Al-Jam'iyatul Washliyah tersebut adalah saling berhubungaan dan berkaitan, sehingga merupakan suatu proses atau tahapan yang harus di jalankan oleh setiap murid untuk mendapat predikat lulusan sekolah Al-Jam'iyatul Washliyah. Di karenakan seluruh jenjang pendidikan tersebut berorientasi pada agama,menyebabkan lulusan sekolah tersebut di persiapkan untuk menjadi kiai atau pendakwah di lingkungan masyarakatnya.

\section{Ulama Terkenal Di Kota Binjai}

Ada beberapa tokoh Agama yang ikut mengembangkan agama Islam di Kota Binjai. Salah satunya yaitu Syeikh Abdul Halim Hasan. Syeikh Abdul Halim Hasan lahir di Binjai pada tanggal 15 mei 1901. Orang tuanya bernama H. Hasan, seorang petani. Masa kecil Abdul Halim Hasan Binjai mencerminkan seorang anak yang haus 
akan ilmu-ilmu keIslaman. Banyak hal yang membuktikan bahwa beliau adalah seorang yang rajin dalam menuntut ilmu. Pada masa selanjutnya, Abdul Halim Hasan beraktifitas dalam dunia kelimuan Islam. Beliau mengajar di Universitas Islam Sumatera Utara. Pribadi seorang guru yang dimiliki oleh Abdul Halim Hasan mencerminkan seorang guru yang ideal yang sederhana. Kesederhanaan beliau dapat dirasakan oleh orang-orang yang bergaul dengan beliau, baik dari kalangan mahasiswa, tokoh akademis maupun masyarakat pada umumnya. Kesederhaan itu tidak hanya terlihat dalam penampilan beliau tapi juga dalam bertutur dan mengekspresikan ideide beliau baik dalam tulisan, perkuliahan ataupun dalam aktifitas lainnya.

Istimewanya adalah bahwa kesederhanaan tersebut ternyata disertai dengan wawasan dan pengetahuan yang luas dalam bidang keilmuan yang beliau dalami. Semua orang yang bergaul dengan beliau mengakui bahwa Abdul Halim Hasan adalah seorang yang luas dan dalam pengetahuannya. Kedalaman ilmu dan luasnya wawasan yang beliau memiliki kemudian membentuk seorang ulama yang terkenal dengan pemikiran yang moderat. Kemoderatan tokoh ini sebagai seorang dosen diakui oleh mahasiswanya, begitu juga dalam ruang lingkup yang lebih luas, moderatisme yang merupakan salah satu keistimewaan Abdul Halim Hasan Binjai akan terlihat dalam pemikirannya, seperti yang terlihat dalam tulisan-tulisan beliau, termasuk pada Tafsir Ahkam.

Salah satu bentuk moderatisme pemikiran beliau adalah sikapnya yang tidak pernah mematok yang mana yang benar dalam pemikiran. Hal ini memang akan terlihat pada diri seorang tokoh yang memahami betul bagaimana sebuah pemikiran muncul dan berbeda dengan yang lainnya.

Prof. DR. H. M. Yassir Nasution, seorang tokoh pendidikan Sumatera Utara yang juga pernah berguru kepada Abdul Halim Hasan menyatakan bahwa beliau tidak akan menyalahkan pendapat-pendapat atau ide-ide yang muncul dari mahasiswanya. Moderatisme ini memang sudah menjadi ciri khas pada tokoh yang satu ini. Ada satu hal lainnya yang sungguh istimewa yang terdapat pada diri Abdul Halim Hasan, yakni partisipasinya sebagai pengurus penting di dua ormas besar yang saling berbeda yakni 
Muhammadiyah dan al-Washliyah. Dua ormas besar ini dikenal saling berseberangan dalam banyak hal. Akan tetapi lagi-lagi kemoderatan beliau telah menciptakan seorang tokoh yang bisa bersikap dengan akurat di posisinya.

Sejak tahun 1920 Abdul Halim Hasan telah mulai mengajar di Binjai hingga tahun 1947. Beliau memberikan pelajaran-pelajaran agama dengan bijaksana dimana dalam pelaksanaan pengjarannya semua pokok - pokok masalah yang muncul diuraikan secara terbuka dan terus terang, serta mengambil keputusan secara adil tanpa terpengaruh oleh suatu golongan tertentu.

Beliau memegang beberapa tugas dan jabatan selama hidupnya, diantaranya menjadi ketua umu Al-Hilal (Organisasi Pemuda) Kampung Limau Sundai, anggota Majelis Syar'iy 1937 di Binjai, Ketua Umum Majelis Islam Tinggi (MIT) tahun 1943 di Binjai, Kepala Jawatan Agama Kabupaten Langkat/Binjai sampai pensiun, Guru besar UISU Medan dan masih banyak lagi.

Pada hari Juma'at 14 November 1969 beliau mengalami sakit dan sempat di rawat di Rumah Sakit PNP II Bangkatan Binjai untuk dirawat. Kemudian pada tanggal 15 November 1969 Abdul Halim Hasan kembali ke Rahmatullah dalam usia 68 tahun 6 bulan. Beliau dimakamkan di pemakaman tanah waqaf Kampung Limau Sundai Binjai. Kyai H. Abdul Qarim merupakan salah satu ulama terkemuka di Kota Binjai, beliau sempat menjabat sebagai kepala madrasah Jamiyatul Khairiyah dulunya madrasah ini di pimpin al ustad H.Muhammad Nur Al-Faqih namun setelah pembangunan madrasah yang baru disebelah mesjid raya Bijai saat ini Madrasah Jamiyatul Khairiyah di pimpin oleh Kh.Abdul Qarim . Dalam membina dan mengasuh madrasah ini beliau dibantu oleh Almarhum KH.Abdul Halim Hasan. KH.Abdul Qarim memimpin dan mengasuh madrasah hanya sampai tahun 1927. Hal ini disebabkan karena beliau diangkat dan ditugaskan sebagai mufti menggantikan al ustad Muhammad Nur Al Faqih.

Salah satu bukti sejarah yang di tinggalkan oleh Almarhum K.H.Abdul Qarim ialah mesjid KH.Qarim yang berada di Jalan KH.Abdul Qarim dikeluruhan Rambung Dalam Kecamatan Binjai Selatan. Pengaruh yang diberikan Almarhum KH.Abdul Qarim terhadap masyarakat di kota Binjai sangat besar, sehingga nama beliau di 
abadikan menjadi salah satu nama di Kota Binjai. Beliau di makamkan pada tahun 1870 di kecamatan Rambung Barat Binjai Selatan dan letaknya di pekarangan Masjid Kyai Karim. Haji Zainal Ariffin Abbas, beliau adalah pengarang buku-buku agama termasuk dalam jumlah yang banyak. Di antara karangannya Peri Hidup Rasulullah s.a.w, yang merupakan sirah Nabi Muhammad s.a.w. yang paling lengkap dan ilmiah dalam bahasa Indonesia. Beliau ialah seorang pengajar, penulis, pendakwah, ilmuwan, pedagang, petani, industriawan, birokrat, bahkan politisi dan negarawan.

Haji Zainal Arifin Abbas pernah mengajar di Arabiyah School Binjai untuk mengajar agama dan ilmiah. Haji Zainal Ariffin Abbas bersama dengan Ustadz Haji Abdul Halim Hasan dan Haji Abdul Rahim Haitami pernah mengarang bersama dan menghasilkan terjemahan dan Tafsir Al-Qur'an pada tahun 1355 H/1936 M. Mereka diberi gelartiga serangkai dalam penyusunan Tafsir Al-Qur'an oleh Pangeran Langkat Hulu di Binjai Tengku Amir Hamzah.

\section{Kampung Limau Sunde}

Limau Sunde saat ini merupakan salah satu nama kelurahan yang terletak di kecamatan Binjai Barat. Limau Sunde merupakan salah satu kampung Islam yang tertua di Kota Binjai. Sekitar 99\% masyarakat yang menetap atau tinggal di Limau Sunde beragama Islam dan bahkan sampai sekarang.

Nama Limau Sunde sendiri berasal dari nama jeruk limau, karena di sekitar kampung Limau Sunde banyak terdapat tumbuhan jeruk limau. Kampung Limau Sunde awalnya di tempati oleh sebagian besar suku mandailing dan melayu. Pengulu atau lurah pertama di kampung Limau Sunde ini adalah tengku kolok. Dan kemudian setelah meninggal jabatannya digantikan oleh Tengku Tehat. Sejak awal salah satu peraturan yang di berikan oleh tengku yang menjadi kepala kampung adalah seseorang boleh menetap dan membeli tanah di kampung Limau Sunde ini jika ia beragama Islam. Hal ini yang menyebabkan secara turun-temurun masyarakat yang tinggal di Limau Sunde beragama Islam. 
Limau Sunde menghasilkan banyak orang-orang yang berpengaruh di Kota Binjai. Sseperti ulama-ulama terkenal yaitu Syeikh Muhammad Isa yang menyebarkan agama Islam di Kota Binjai di sekitar tahun 1800-an dan K.H. Abdul Karim yang merupakan ulama dan sekaligus pencetus diadakannya Musabaqah Tilawatil Qur'an Nasional pertama.

\section{PENUTUP}

Binjai merupakan suatu kota yang terletak di antara kabupaten Langkat dan Deli Serdang. Kota Binjai terbagi menjadi 5 kecamatan yaitu Binjai utara, Binjai Selatan, Binjai Timur, Binjai Barat, dan Binjai Kota. Kota Binjai secara historis terletak diantara dua kesultanan melayu yang besar, yaitu Kesultanan Langkat dan Kesultanan Deli. Luasnya wilayah kekuasaan kedua kesultanan ini berdampak pada perkembangan wilayah - wilayah lain di sekitarnya. Kota Binjai sendiri mengalami perkembangan karena bagian dari luasnya wilayah kekuasaan Kesultanan Langkat.

Kota Binjai merupakan berpenduduk mayoritas penganut agama Islam, Islam menjadi mayoritas di Kota Binjai yang disebabkan oleh keberadaan Kesultanan Asahan dan daerah atau wilayahnya yang bermayoritas suku Melayu. Persebaran agama yang mengalami perkembangan pesat hingga kini menjadikan agama-agama lain seperti Kristen, Hindu, Budha juga mengalami perkembangan akibat mobilitas penduduk dari waktu ke waktu.

Masuk dan berkembangnya agama Islam tidak terlepas dari pengaruh Kesultanan Langkat. Islam masuk ke Kota Binjai melalui dua cara yang pertama karena perluasan daerah yang dilakukan oleh Kesultanan Langkat dan yang kedua dibawa oleh para pedagang dari negara tetangga yang mengadakan transaksi dagang di antara Muara Sungai Bingai dan Aliran sungai Wampu. Letaknya yang strategis menjadikan Binjai kota yang berkembang pesat dan mengalami banyak perkembangan di beberapa 
bidang seperti perekebunan dan infrasturktur. Hal ini menyebabkan banyaknya pemukiman-pemukiman baru yang berkembang di Binjai dan menjadikan perkembangan islam berkembang di Binjai.

Jejak-jejak Islam di Kota Binjai yang masih dapat di lihat sampai sekarang adalah berupa masjid, makam, kampung, madrasah atau sekolah, dan ulama-ulama. Jejak Islam tersebut tersebar di seluruh Kota Binjai. Mesekipun Kota Binjai mengalami perkembangan zaman, namun masih terdapat beberapa peninggalan sejarah Islam yang masih bisa dilihat keberadaannya.

\section{DAFTAR BACAAN}

Aceh, Aboebakar (1985). Sekitar Masuknya Islam ke Indonesia. Solo: Ramadhani Azra, Azyumardi (1998). Jaringan Ulama. Bandung : Mizan

Koentjaraningrat (2009). Pengantar Ilmu Antropologi. Jakarta: PT Rineka Cipta Kuntowijoyo (2003). Metodologi Sejarah. Yogyakarta: PT. Tiara Wacana Kuntowijoyo (2006). Budaya dan masyarakatnya. Yogyakarta: Tiara Wacana

Loeb, Edwin (2013). Sumatra : Sejarah Dan Masyarakatnya. Yogyakarta : Penerbit Ombak

Pane, Imam Mahdi (2010). Nilai Historis Tentang Peninggalan Historis Sebagai Cagar Budaya Di Kota Binjai. Skripsi tidak diterbitkan. Medan: Universitas Negeri Medan.

Pulungan, Abbas (2008). Perkembangan Islam Di Mandailing. Bandung: Citapustaka Media Perintis

Reid, Anthony (2011). Menuju Sejarah Sumatera : Antara Indonesia dan Dunia. Jakarta: Obor

Renier, G.J (1997). Metode Dan Manfaat Ilmu Sejarah. Yogyakarta : Pustaka Pelajar Saifullah (2010). Sejarah dan Kebudayaan Islam di Asia Tenggara. Yogyakarya: Pustaka Pelajar

Siregar, Nur Hikmah (2013). Eksistensi Al-Jam'iyatul Washliyah Dalam Bidang Pendidikan di Kecamatan Binjai Kota di Kota Binjai Tahun 1940-2012. Medan: Universitas Negeri Medan

Syam, Nur (2005). Islam Pesisir. Yogyakarta : LKIS Yogyakarta

Yatim, Badri (2008). Sejarah Peradaban Islam. Jakarta: Pt. Raja Grafindo Persada 